$r e c e n z e$ 



\section{Literární dějiny jako př́běh boje o a za literaturu}

DLASK, Jan: Dějiny finskošvédské literatury v perspektivě bourdieuovské sociologie. Červený Kostelec: Pavel Mervart, 2018. 278 s. ISBN 978-80-7465-318-6

Psát dějiny literatury je komplikovaný úkol: vyžaduje mimo jiné široké znalosti a precizní analytické a kritické schopnosti ve výběru toho, co je pro danou literaturu specifické, danou metodologií postihnutelné a pro přijímající prostředí podstatné. Jedná se také o úkol nanejvýš nevděčný: výběrem spisovatelů autor či autoři vstupují na tenký led, kdy na jednu stranu musejí do jisté míry dostát očekávání prostředí, pro které je podobné kompendium určeno, na straně druhé však mohou toužit po jistém inovativním až reinterpretačním přístupu k materiálu, jejž reflektují.

V ještě složitějším (či možná jednodušším?) postavení se ocitá autor, jenž si klade za cíl přijímajícímu prostředí představit literaturu neznámou, nebo o které má prostředí informace pouze kusé, útržkovité či - v nejhorším případě $-\mathrm{z}$ různých důvodů deformované, např. tím, že se jedná o literaturu určité menšiny, kterou do jisté míry zastiňuje literatura a obecně kultura v dané zemi většinová. Toto riziko se rozhodl podstoupit Jan Dlask (*1974), působící jako odborný asistent se specializací na finskou literaturu na Ústavu germánských studií FF UK, jehož monografii Dějiny finskošvédské literatury v perspektivě bourdieuovské sociologie vydalo v loňském roce nakladatelství Pavel Mervart.

Publikace je výsledkem autorova dlouhodobého zájmu jak o švédskojazyčnou menšinu ve Finsku, její literaturu a kulturu v synchronní i diachronní perspektivě, tak o předmětnou metodologii, kterou použil již ve své disertační práci obhájené v roce 2010 ( $\mathrm{z}$ níž ostatně čerpá i v této knize, a to v kapitole o debatě dvou velikánů 70. let, Christera Kihlmana a Henrika Tikkanena). Před samotným zpracováním materiálu je stručně představena metodologie Pierra Bourdieaua vycházející z knihy Pravidla umění: Vznik a struktura literárního pole (1992, česky 2010); Jan Dlask ji však aplikuje na typově odlišný a vnitřně různorodější materiál, než je francouzská kultura dominantní ve Francii 19. století. 
Autorovým cílem je poodkrýt půdorys existence a zákonitosti fungování literatury menšinového společenství; to sice existuje do velké míry nezávisle na většině a vytváří si svébytné literární struktury, mezi ním a majoritou však ve zkoumaném období (od začátku 20. století do současnosti) nedochází k vyhroceným identitárním sporům. Švédskojazyčné kulturní pole ve Finsku je navíc specifické rozdělením na dominantní městské (helsinské) centrum a periferii nacházející se v Turku a přilehlých šérách, na Ålandských ostrovech a především v kraji Pohjanmaa (švédsky Österbotten) na severozápadním pobřeží země. Tyto dvě sociálně a ekonomicky rozdílné oblasti (v hlavním městě historicky přináleželi finští Švédové především mezi vrstvy obyvatelstva s vyšším až vysokým statusem, na venkově pak k vrstvám nižším: jednalo se typicky o chudé rybáře) mezi sebou během 20. století vedly dialog o podstatě finského švédství i o právu považovat se za jeho reprezentanty a podílet se tak na vytváření jeho obrazu.

Na rozdíl od „autoritativního“ či „výkladového“ diskurzu tradičních literárních dějin bourdieuovská perspektiva zdůrazňuje mimo jiné genezi kanonizace daného spisovatele, přičemž stejné pozornosti jako procesům úspěšným se dostává i těm nezdařeným. Právě napsání těchto „alternativních dějin“ je jedním z cílů publikace Jana Dlaska.

Bourdieuův sociologický přístup autorovi umožňuje popsat finskošvédskou literaturu nikoli formou romantizující koláže solitérních a již (v národním a částečně i mezinárodním, hlavně severském, kontextu) kanonizovaných spisovatelů-velikánů, nýbrž z pohledu interakce mezi jednotlivými aktéry (spisovateli, recenzenty, periodiky i nakladatelstvími), tj. literární praxe v širokém slova smyslu. Jak Jan Dlask skrze svou analýzu dokazuje, literární hodnota není dána per se a je výsledkem mnohdy i desítky let trvajících střetů, přičemž nezbytnou podmínkou pro přiřknutí hodnoty konkrétním autorům či celým směrům (např. boje o Edith Södergranovou a přijetí, resp. interpretaci, finskošvédského modernismu 20.-30. let) je vůle dominantních aktérů.

Ačkoli publikace nezbytně obsahuje i základní informace o autorech, soustředí se na jejich kontextualizaci v rámci dané historické situace. Toto může však místy působit poněkud roztřrištěně, stejně jako místy nejasné (či minimálně vůči čtenáři ne příliš práátelské) odkazování na díla referencemi typu „autorova první kniha“, přičemž čtenář musí listovat několik stránek dozadu, aby si připomněl, o které dílo se jedná. Metoda také umožňuje Dlaskovi pojednat jak o hráčích na literárním poli dominantních, tak o marginalizovaných i veskrze marginálních, jejichž okrajovost Dlask de facto v textu sám přiznává, když na některých 
místech „pro úplnost“ uvádí pouhý výčet jmen, a o jejichž zařazení lze tedy diskutovat. Podobně netypicky může na čtenáře uvyklé na tradičněji pojaté literárněhistorické publikace působit kapitola, ve které Dlask pomocí podrobných statistik rozebírá „sociální, genderové a geografické aspekty“ finskošvédské literatury.

Samotný text by si zasloužil o něco pečlivější redakci (velikost písma, opakující se fráze, přemíra někdy nejasného a často zbytečného odkazování typu „viz níže/výše“) i zcizelování (místy jednotlivé kapitoly působí jako samostatné studie, kdy jsou opětovně uváděna některá fakta).

Jedná se jistě o počin minimálně v kontextu české reflexe severských literatur záslužný, obzvláště za předpokladu, že má kniha sloužit (slovy autora) pro povzbuzení zájmu o finskošvédskou literaturu mezi studenty. Kniha je ovšem také cenným příspěvkem k otázce možností psaní literárních dějin obecně: Jaké aktéry a kontexty zahrnout a jaké už ne? Jak tento výběr co nejcelistvěji a nejsrozumitelněji předat přijímajícímu prostředí?

Jak je možno sledovat na příkladu publikace Jana Dlaska, psát dějiny literatury jako příběh popisující předivo vazeb mezi jednotlivými aktéry se zdá být pro pochopení nuancí literárního života nezbytností. A to obzvláště v okamžiku, kdy otevírají čtenářům nové obzory.

Jan-Marek Šík 